\title{
The Impact of Pedagogy and Teachers' Professionalism Competencies Towards Teachers' Performance of State Vocational School in Sekayu
}

\author{
Rahmawati $^{1 *}$, Happy Fitria ${ }^{2}$, Rohana $^{2}$ \\ ${ }^{I}$ SMK Negeri 3 Sekayu \\ ${ }^{2}$ Universitas PGRI Palembang, Indonesia \\ "Corresponding author.Email: jilbaber.rahma@gmail.com
}

\begin{abstract}
This research is conducted toward state vocational schools' teachers in Sekayu. The research problems are 1. Is there any impact of pedagogy competencies toward teachers' performance of state vocational schools in Sekayu? 2. Is there any impact of professionalism competencies toward teachers' performance of state vocational schools in Sekayu? And 3. Is there any impact of pedagogy and professionalism competencies at the same time toward teachers' professionalism of state vocational schools in Sekayu? This research uses a quantitative methodology which is spreading a questionnaire to 110 state vocational schools' teachers in Sekayu. Furthermore, the gathered data is analyzed by using Statistical Product and Service Solution (SPSS). The research findings show that 1 . There is an impact of pedagogy competencies toward teachers' performance of state vocational schools in Sekayu with the number of $50 \%$ with thitung equal to 10.314 and ttabel equal to $19.822,2$. There is an impact of professionalism competencies toward teachers' performance of state vocational schools in Sekayu with the number of $53 \%$ with tvalue equal to 10.977 and ttable equal to 19.822 , and 3. There is an impact of pedagogy and professionalism competencies at the same time toward teachers' professionalism of state vocational schools in Sekayu with the number of $58 \%$ with fvalue equal to 74.919 and ftable equal to 3.08. The conclusion of this research is in improving teachers' performance of state vocational schools in Sekayu needs pedagogy and professionalism competencies.
\end{abstract}

Keywords: Pedagogic Competence, Professional Competence, Teacher Performance

\section{INTRODUCTION}

Educational activities consist of two parties, namely teachers and students, and the presence of both parties is the involvement of human relations [1]. According to Nawawi, the low quality of education at every level of education is one of the key problems facing the Indonesian country [2]. Efforts are being made to raise the national education standard, namely numerous training courses to enhance teacher competence in the procurement of books and teaching materials, the enhancement of educational facilities, and the quality of school management infrastructure. Nonetheless, different measures of the quality of education have not demonstrated noticeable progress [3]. Quality teachers are capable of efficiently and effectively carrying out education, teaching, and training. To achieve the educational standards set according to Nurmalasari, skilled teachers are thought to be able to inspire students to maximize their ability [4].

Teachers play a critical role in attempts to increase the quality of formal education. As learning agents, teachers are expected to be willing, within the context of educational development, to carry out the learning process as well as possible. Law No. 14 of 2005 on teachers and teaching staff Article 4 stresses that teachers serve as teaching staff to enhance the quality of national education, so that teachers are required to have certain conditions, one of which is competence, to carry out their duties properly. As part of teacher professionalism, educators must have many qualifications and competencies in order to be able to fulfill their duties and obligations in the teaching profession [5] In general, the educational history, experience, and teaching materials of teachers in the implementation of teaching is closely linked to the level of teacher service in learning [6].

According to the Explanation of the Regulation of the Minister of National Education of the Republic of Indonesia No 16 of 2007 concerning Academic Qualification Standards and Teacher Competencies, the government has formulated four types of teacher competencies in the national education policy. Teacher competency standards are developed from the four main competencies, (1) technical competence;

(2) 
pedagogical competence; (3) psychological competence; and (4) competence in the area of personality.

All teacher competencies are competencies that, when working as a teacher simply must be learned. These four instructor competencies will carry a teacher's authority, both academically and morally, to an optimal teacher.

Dependent on Minister of National Education Regulation No. 16 of 2007, the technical teacher competencies in book 4 specified that the pedagogical competencies that teachers must have are as follows: (1) Understanding the character of students, (2) Mastering learning philosophy and learning concepts, (3) Capable of designing curriculum, (4) Design of instructional learning experiences, (5) Growth of student ability, (6) Contact with students, (7) Learning assessment and evaluation [7].

Technical competence is the capacity of teachers to thoroughly and profoundly master learning content and, according to Yusup, to fulfill their duties and authority in the teaching profession with high skills. Notes in book 4 Professional Teacher Competencies that the professional competencies that teachers must possess are as follows: (1) mastering content, structure, principles, and scientific patterns of thinking that help the topic being taught, (2) mastering the principles of integrity and basic knowledge of the subjects discussed, (3) developing innovative learning materials,(4) sustainably developing professionalism through reflective intervention, (5) leveraging information and communication technologies to improve oneself.

Success is the function that can be done in an organization by an individual or group of persons in compliance with their respective authorities and obligations in an attempt to attain the aims of the organization concerned officially, in violation of the law and accordance with ethics and morality [8].

Instructor success can be viewed as a condition for demonstrating the capacity of a teacher to fulfill his duties and explaining the teacher's actions during the learning process [9]. Besides, in their book entitled Performance Theory and Evaluation, [10] propose teacher performance metrics in order to assess teacher performance as follows: (1) job efficiency, (2) work speed/commitment, (3) work effort, (4) work skills, (5) communication.

\section{METHODS}

The method used in this research is quantitative method of an ex post facto the analysis methodology. Then, instructor output is the dependent variable (Y). This research looked at, teacher success as a consequence or influence, then, as a reason, pedagogical ability and technical competence results in good or bad performance of teachers. Teachers at SMK Negeri Sekayu District were the test subjects. In this analysis, the population of all teachers working in public vocational high schools in the district of Sekayu, namely SMKN 1, SMKN 2 and SMKN 3 Sekayu, totaling 152 persons, was based on the Slovin method to assess the number of samples used in this study. The number of samples is 110 instructor samples using the Slovin formula.

The research data was obtained using a questionnaire and a documentation review to determine the effect of teacher pedagogical competence and professional competence on teacher performance. The instrument was used to assess the efficacy of using Virtual Reality-based learning media to increase student engagement and learning outcomes in a science subject. The findings showed differences in the interests of students in researching science before and after the posttest was conducted in experimental and control groups to determine the rise in the motivation and learning outcomes of each student based on the data obtained. Science, although the learning process in the control the group did not use media based on Virtual Reality. In each group, the post-test was carried out since the operation has been completed.

\section{RESULTS AND DISCUSSION}

\section{1) Descriptive Statistical Analysis}

The distribution of data frequency of instructor output factors, pedagogical competence and technical competence of teachers are as follows:

Table 1. Descriptive Statistical Analysis Results

\begin{tabular}{|c|c|c|c|c|}
\hline \multicolumn{5}{|c|}{ Statistics } \\
\hline & & $\begin{array}{c}\text { Pedagogical } \\
\text { competence }\left(\mathrm{X}_{1}\right)\end{array}$ & $\begin{array}{c}\text { Professionalism } \\
\text { Competencies }\left(\mathrm{X}_{2}\right)\end{array}$ & $\begin{array}{c}\text { Teacher } \\
\text { Performance (Y) }\end{array}$ \\
\hline \multirow[t]{2}{*}{$\mathrm{N}$} & Valid & 110 & 110 & 110 \\
\hline & Missing & 0 & 0 & 0 \\
\hline \multicolumn{2}{|r|}{ Mean } & 47.96 & 50.69 & 54.39 \\
\hline \multicolumn{2}{|r|}{ Median } & 48.00 & 51.00 & 55.00 \\
\hline \multicolumn{2}{|r|}{ Mode } & 48 & 51 & 55 \\
\hline \multicolumn{2}{|r|}{ Std. Deviation } & 5.479 & 4.490 & 5.516 \\
\hline \multicolumn{2}{|r|}{ Skewness } & -.092 & .204 & -.412 \\
\hline \multicolumn{2}{|r|}{ Std. Error of Skewness } & .230 & .230 & .230 \\
\hline \multicolumn{2}{|r|}{ Kurtosis } & -.421 & -.230 & .081 \\
\hline \multicolumn{2}{|r|}{ Std. Error of Kurtosis } & .457 & .457 & .457 \\
\hline \multicolumn{2}{|r|}{ Minimum } & 36 & 41 & 35 \\
\hline \multicolumn{2}{|r|}{ Maximum } & 59 & 62 & 64 \\
\hline
\end{tabular}


Data on pedagogical competence, namely the lowest score of 36 and the highest score of 59, the mean value (mean) of 47.96 , the middle value (median) of 48.00 , mode 48.00 , and the variance of the standard deviation of 5.48, were collected from the respondents' responses in the table of descriptive statistical analysis results. The results of the equations above indicate that the magnitude of skewness is -0.922 , from these results, the value of skewness and kurtosis is found in the region between -2 and +2 , and the kurtosis value is -0.421 , so it can be assumed that the distribution of the pedagogic competency value sample data is standard.

The lowest score was 41 for the teacher's technical integrity, the highest score was 62 , the average count (mean) was 50.69, the mean value (median) was 51.00, the mode was 51.00, and the standard deviation was 4.49. The results of the following equation reveal that the skewing value is 0.204 and the kurtosis value is 0.230 , respectively. The skewness and kurtosis values from these results are in the range of -2 to +2 , indicating that the distribution of the pedagogical competence value data sample is normal (in Kesumawati, 2018: 55).

For teacher evaluation results in table 1 above, the lowest score is 35 and the highest score is 64, the the average (mean) count is 54.38 , the average (median) rating is 55.00, the model is 55.00, and the standard deviation is 5.516. The results of the equations above suggest that the skewness value is -0.412 and the kurtosis value is 0.081 , respectively. The skewness and kurtosis values are found in the region between -2 to +2 from these results, so it can be said that the distribution of the data sample of the pedagogical competency value is usual [11].

\section{2) Testing Data Analysis Requirements}

\section{a. Normality Test}

The effects of the estimation on instructor success $(\mathrm{Y})$ of the normality of pedagogical competence $\left(\mathrm{X}_{1}\right)$ and technical competence $\left(\mathrm{X}_{2}\right)$ variables can be inferred as follows:
1. The report on pedagogical ability $\left(\mathrm{X}_{1}\right)$ has a relevant value of $0.086>0.05$, so the data is usually transmitted.

2. Data on work motivation $\left(\mathrm{X}_{2}\right)$ has a relevant value of $0.200>0.05$, so the data is typically transmitted.

3. The output data for teachers (Y) has a meaningful value of $0.077>0.05$, so the data is typically transmitted.

\section{b. Linearity Test}

Results of measurements via the program framework SPSS version 26 are obtained:

1. 0.964 is the significant value on the linearity axis. The significant value of linearity from the ANOVA table is above $0.964 \geqslant a(\alpha=0.05)$ depending on the linearity measure criterion, so the relationship between pedagogic skill and instructor success is linear.

2. Based on the linearity test criteria, the significant value of linearity from the ANOVA table is over $0.986 \geqslant a \quad(a=0.05)$ based on the linearity test criteria, so the association between skilled teacher expertise and teacher success is linear.

\section{c. Multicollinearity Test}

Multicollinearity between the variables in this regression model of pedagogical competence, teacher technical competence, and teacher performance findings of the research study by SPSS version 26 fulfilled the criteria for further analysis, Specifically, from the results of the normality, linearity, and multicollinearity tests, partial and simultaneous hypothesis testing analysis between the variables evaluated using multiple linear regression analysis.

\section{3) Hypothesis Test}

\section{a. Multiple Linear Regression Coefficient Analysis}

Table 2. Results of Coefficient Analysis of Linear Regression Several

\begin{tabular}{|c|c|c|c|c|c|c|}
\hline \multicolumn{7}{|c|}{ Coefficients $^{\mathrm{a}}$} \\
\hline & \multirow{2}{*}{ Model } & \multicolumn{2}{|c|}{$\begin{array}{c}\text { Unstandardized } \\
\text { Coefficients }\end{array}$} & \multirow{2}{*}{$\begin{array}{c}\begin{array}{c}\text { Standardized } \\
\text { Coefficients }\end{array} \\
\text { Beta }\end{array}$} & \multirow[t]{2}{*}{$\mathrm{t}$} & \multirow[t]{2}{*}{ Sig. } \\
\hline & & B & Std. Error & & & \\
\hline \multirow[t]{3}{*}{1} & (Constant) & 11.764 & 3.659 & & 3.215 & .002 \\
\hline & $\begin{array}{l}\text { Pedagogical } \\
\text { competence }\left(X_{1}\right)\end{array}$ & .352 & .093 & .362 & 3.794 & .000 \\
\hline & $\begin{array}{l}\text { Professionalism } \\
\text { Competencies }\left(\mathrm{X}_{2}\right)\end{array}$ & .501 & .106 & .452 & 4.732 & .000 \\
\hline
\end{tabular}

It is derived from the table above that the coefficient is constant $=11.764$, coefficient $\mathrm{X} 1=0.352$ and coefficient X2 $=0.501$ in order to achieve the multiple linear regression equation. 


$$
\begin{aligned}
& Y=a+b_{1} X_{1}+b 2 X_{2} \\
& Y=11,764+0,352 X_{1}+0,501 X_{2} \\
& \text { Information: } \\
& Y \text { : Success of an instructor } \\
& X_{1} \text { : Excellence in pedagogy } \\
& X_{2} \text { : Technical Integrity for Teachers }
\end{aligned}
$$

\section{b. Analysis of The Coefficient of Determination}

To evaluate the value of the association between the independent variable $(\mathrm{X})$ consisting of pedagogical competence $\left(\mathrm{X}_{1}\right)$ and teacher technical competence $\left(\mathrm{X}_{2}\right)$ and the dependent variable $(\mathrm{Y})$, namely teacher efficiency, the coefficient of determination $\left(R_{2}\right)$ is used.

The following findings were derived from the results of multiple linear regression analysis via the SPSS version 26 software program:

Table 3. Results of the Analysis of the Determination of Variables $X_{1}$ dan $X_{2}$ Simultaneously against $Y$

\begin{tabular}{|c|c|c|c|c|}
\hline \multicolumn{5}{|c|}{ Model Summary } \\
\hline Model & $\mathrm{R}$ & $\mathrm{R}$ Square & Adjusted R Square & Std. Error of the Estimate \\
\hline 1 & $.764^{\mathrm{a}}$ & .583 & .576 & 4.672 \\
\hline \multicolumn{3}{|c|}{ a. Predictors: (Constant), Pedagogical competence $\left(\mathrm{X}_{1}\right)$, Professionalism Competencies $\left(\mathrm{X}_{2}\right)$} \\
\hline
\end{tabular}

Table 3 indicates that the $\mathrm{R}$ Square value is 0.583 , so the decision coefficient is $58 \%$, so it can be inferred that teacher output is impaired by pedagogical competence $\left(\mathrm{X}_{1}\right)$ and teacher technical competence $\left(\mathrm{X}_{2}\right)$, the remaining $58 \%$ is affected by other factors not included in the two variables.

\section{a. Partial Linear Regression Analysis (t-Test)}

The following knowledge is seen from the effects of the partial linear regression analysis ( $t$ test) on the variables of pedagogical competence $\left(\mathrm{X}_{1}\right)$ and teacher technical competence $\left(\mathrm{X}_{2}\right)$ on teacher success ( $\mathrm{Y}$ ) using the software program framework SPSS version 26:

1. The important value of $0.000<5$ percent, so Ho is denied, which implies that the variable of pedagogical competence $\left(\mathrm{X}_{1}\right)$ has an effect and is statistically significant at 5 percent on the variable of teacher success (Y). The value of the $\mathrm{t}$-count is 10.314 , and the value of the t-table is 1.9822 , so t-count> t-table, Ho is also rejected, which means that the pedagogical competency variable $\left(\mathrm{X}_{1}\right)$ has an effect and is statistically relevant at $5 \%$ of the Instructor output variable (Y).

2. The significant value of $0.000<5 \%$, so Ho is excluded, which means that the vector technical competence $\left(\mathrm{X}_{2}\right)$ has a statistically relevant and significant influence on the instructor output indicator at $5 \%(\mathrm{Y})$. The value of the count is 10.977 and the value of the table is 1.9822 , so tcount> table means that $\mathrm{Ho}$ is refused, the variable of professional competence $\left(\mathrm{X}_{2}\right)$ has a statistically important and significant effect on the variable of instructor success at $5 \%(\mathrm{Y})$.

\section{b. Simultaneous Multiple Regression Analysis}

Table 4. Results of Simultaneous multiple Linear Regression Analysis (f-Test).

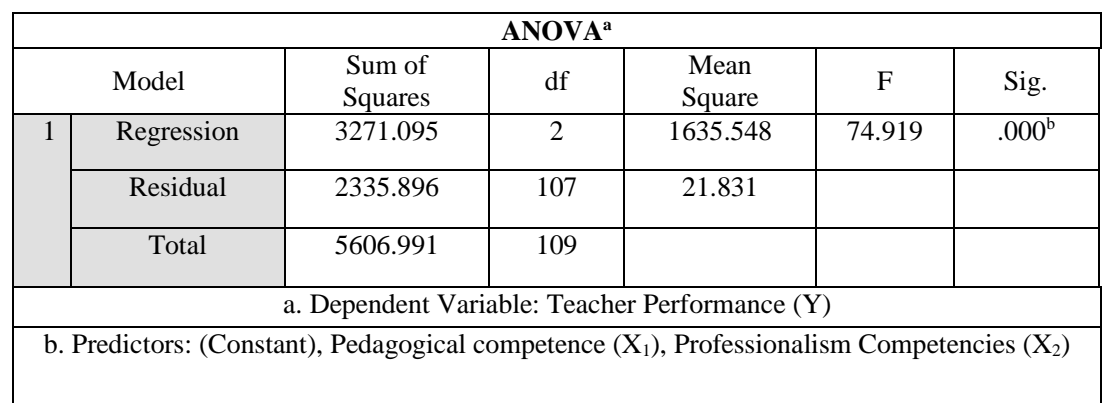

It is understood, based on the output of table 4, that the importance of significance for the impact on teacher performance $(\mathrm{Y})$ of pedagogical competence $\left(\mathrm{X}_{1}\right)$ and teacher technical competence $\left(\mathrm{X}_{2}\right)$ concurrently is 0.000 $<0.05$, and the $\mathrm{F}$ value is 74.919 archer performance (Y). 


\section{The Influence of Pedagogical Competence on Teacher Performance in Vocational High School Negeri Sekayu District}

Pedagogical competence is very significant because it is a determinant of the progress of the learning process that specifically influences the learning ability, namely (1) mastering the characteristics of students, based on the findings of data analysis, there is an impact of pedagogical competence $\left(\mathrm{X}_{1}\right)$ on teacher performance (Y). (2) mastering the philosophy of learning and the concepts of educational learning, (3) program development, (4) educational learning experiences, (5) student ability development, (6) collaboration with student participants, (7) learning assessment and appraisal. In handling student learning, including knowing students, pedagogical integrity is very critical. Implementation of instructional curriculum, assessment of learning outcomes, and growth of students so that teachers can grow pupil ability, which eventually impacts the enhancement of teacher learning performance [12].

The Influence of Teacher Professional Competence on Teacher Performance in Vocational High School Negeri Sekayu District

The impact of teacher professional competence $\left(\mathrm{X}_{2}\right)$ on teacher success $(\mathrm{Y})$ is based on the effects of data review, in line with the results of research by Mardalena, et al [12] entitled The Effect of Academic Oversight and Teacher Professional Competence on High School Teacher Performance."Tanjung Raja District Country ". The findings show that: (1) there is a significant influence of academic oversight on the success of public high school teachers in the district of Tanjung Raja; (2) there is a significant impact of teacher technical expertise on the performance of public high school teachers in the district of Tanjung Raja, (3). An important link occurs between academic oversight and the technical integrity of teachers in the success of public high school teachers in the district of Tanjung Raja [13].

\section{The Influence of Teacher Pedagogic Competence and Teacher Professional Competence on Teacher Performance}

The impact of pedagogical competence $\left(\mathrm{X}_{1}\right)$ and the technical competence of teachers $\left(\mathrm{X}_{2}\right)$ on teacher, success is focused on the effects of data analysis (Y). Bandung City Success of Economic Teachers in Public High Schools. The findings found that technical integrity has an impact on the success of teachers. That is, the higher the technical skill of teachers in the town of Bandung, the higher the success of teachers in economics. The findings of studies in the field demonstrate that when teaching in the classroom, the technical skill of teachers dictates the mastery of teacher content. The higher the teacher's success in the classroom, the more competent the teacher is in mastering the subject involved [14].

\section{CONCLUSION}

In this review, based on data interpretation, hypothesis testing, and discussion of the definitions previously presented, it can be hypothesized as follows: (1) with at-count of 10,314 and at-table value of 1 , 9822 , there is a 50 percent impact of pedagogical competence on teacher success at Vocational High School in Sekayu District; (2) the impact of teacher professional competence on teacher success in the Vocational High School in Sekayu District is 53\% with an at-count of 10,977 and a table of 1,9822, and (3) the effect of both teacher professional competence and pedagogical competence on teacher performance in the Vocational High School in Sekayu District is 58\% with a value of 74,919 and a value of 3,08 . The result of this research is that teachers need to have pedagogical competence and technical competence in order to enhance teacher output in the Vocational High School in Sekayu Region.

\section{ACKNOWLEDGMENT}

Our deepest gratitude goes to Teachers in SMK Negeri 3 Sekayu, Chancellor of Palembang PGRI University, Director of the Postgraduate Program of PGRI Palembang University and the Education Management Study Program of PGRI Palembang University, who have supported us in doing this extraordinary thing. This project is funded independently. We also want to thank our Education Management friends who helped us a lot in a short time frame to complete this project.

\section{REFERENCES}

[1] Siregar, N. S. S. (2017). Persepsi Orang Tua terhadap Pentingnya Pendidikan bagi Anak [Parents' Perceptions of the Importance of Education for Children]. JPPUMA: Jurnal Ilmu Pemerintahan dan Sosial Politik UMA (Journal of Governance and Political Social UMA), Vol. 1 No. 1, 11-27.

[2] Nawawi, A. (2011). Pentingnya Pendidikan Nilai Moral bagi Generasi Penerus [The Importance of Moral Value Education for the Next Generation]. Jurnal kependidikan: insania, 16(2), 119-134.

[3] Ekosiswoyo, R. (2016). Kompetensi pedagogik yang efektif kunci pencapaian kualitas pendidikan [Effective pedagogical competence is the key to achieving quality education]. Jurnal Ilmu Pendidikan Universitas Negeri Malang, Volume 14 No. 2. Halaman 56-63.

[4] Nurmalasari, I. (2018). Pengaruh Kompetensi pedagogik, Kompetensi Pedagogik, dan Kompetensi Profesional Guru Terhadap Kinerja 
Guru SMK Bisnis Manajemen di Kabupaten Klaten [The Influence of Pedagogic Competence, Pedagogic Competence, and Teacher Professional Competence on Teacher Performance in SMK Business Management in Klaten Regency]. Jurnal Wahana Akademika 5(2), 69-85.

[5] Suyanto. (2013). Menjadi Guru Profesional strategi meningkatkan kualifikasi dan kualitas guru di Era Global [Becoming a Professional Teacher is a strategy to improve teacher qualifications and quality in the Global Era]. Jakarta: Erlangga

[6] Sanin, M., \& White, A. L. (2015). Teachers 'Perceptions Related to Characteristics of Professional Environment for Teaching [ Teachers' Perceptions Related to Characteristics of Professional Environment for Teaching]. Eurasia Journal of Mathematics Sciences\& Technology Education, June 2015, Vol. 11 No.3 Hal. 559-575.

[7] Amir, A. S. (2019). 4 Kompetensi Guru Profesional [4 Competence of Professional Teachers]. Yogyakarta: Deepublish.

[8] Aritonang, K. T. (2005). Kompetensi Kerja. Disiplin Kerja Guru Kinerja Guru SMP Kristen BPK Penabur Jakarta Job competence [Teacher Work Discipline Teacher Performance at SMP Kristen BPK Penabur Jakarta]. Dalam Jurnal Pendidikan Penabur Volume IV No. 04 Juli 2005 Halaman 98-106.

[9] Pratami, F., Rizki, A. dkk. (2018). Influence of School Principal and Organizational Climate Supervision on Teachers' Performance. International Journal of Scientific \& Technology Research. Volume 7, Issue 7, July 2018 ISSN 2277-8616 Hal. 228-236.

[10] Uno, H. B., Lamatenggo, N. (2015). Teori Kinerja Dan Pengukurannya [Performance Theory and Measurement]. Jakarta: PT. Bumi Aksara.

[11] Priansa, D. J. (2014). Perencanaan dan Pengembangan Sumber Daya Manusia [Human Resource Planning and Development]. Bandung: Alfabeta

[12] Mardalena., Arafat, Y., \& Fitria, H. (2020). Pengaruh Supervisi Akademik dan Kompetensi Profesional Guru terhadap Kinerja Guru di Sekolah Menengah Atas Negeri di Kecamatan Tanjung Raja [The Effect of Academic Supervision and Teacher Professional Competence on Teacher Performance in Public Senior High Schools in Tanjung Raja District. Universitas PGRI Palembang]. Jurnal Intelektualita: Keislaman, Sosial, dan Sains. Vol. 9 No. 1. $103-$ 114.
[13] Kesumawati, N., \& Ichwan, A. (2018). Statistik Parametrik [Parametric Statistics]. Palembang: Noerfikri Offset.

[14] Hamalik, O. (2006). Proses Belajar Mengajar [Teaching and Learning Process]. Jakarta: PT. Bumi Aksara. 